\title{
The role of communication in organizational culture. Is there a pattern in Spanish fashion companies?
}

\author{
Paloma Díaz-Soloaga
}

How to cite this article:

Díaz-Soloaga, Paloma (2019). "The role of communication in organizational culture. Is there a pattern in Spanish fashion companies?". El profesional de la información, v. 28, n. 5, e280506.

https://doi.org/10.3145/epi.2019.sep.06

Manuscript received on $9^{\text {th }}$ April 2019 Accepted on $8^{\text {th }}$ July 2019

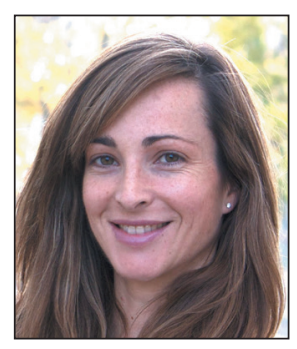

\section{Paloma Díaz-Soloaga}

https://orcid.org/0000-0003-1798-1768

Universidad Complutense de Madrid

Facultad de Ciencias de la Información

Av. Complutense, 3. 28040 Madrid, Spain

pdiaz@ucm.es

\begin{abstract}
The link between organizational culture and efficiency has been widely studied in academia as there is great interest in finding out whether strong and balanced cultures lead to better long-term performance. The aim of this article is to carry out a preliminary analysis of the internal culture of the Spanish fashion sector, focusing particularly on communication as a driving force behind this process. With regard to methodology, we opted for applying an initial factor analysis of the opinions of seven experts and a subsequent one with 40 executives and middle managers in the sector. The findings show that the type of culture in the Spanish fashion companies studied, depends on a range of factors, the role of communication being worth highlighting in the case of the experts, while in the case of executives and middle managers, the so-called emotional salary stands out as an important factor.
\end{abstract}

\section{Keywords}

Organizational culture; Organizational communication; Corporate communication; Internal communication; Intangible management; Labour climate; Creative industries; Fashion; Corporate identity; Companies; Managers.

\section{Introduction}

Organizations have been paying great attention to work culture and working atmosphere since the 1990s (Garmendia, 2006), not only from Human Resources departments, but also from communication, culture and management of intangibles departments (Cújar-Vertel et al., 2013).

Schein (1990) defines organizational culture as a set of behavioural habits generated by the people who make up a company -and that crystallize in the so-called "basic assumptions"- as a consequence of the sustained effort to solve problems both internal and external to the organization. This author-considered the father of this discipline- holds that over time these guidelines constitute the appropriate way to understand and resolve adverse circumstances in organizations. This learning is simultaneously acquired at the cognitive, emotional and behavioural levels. The deepest level of culture is cognitive; the perceptions, language and thought processes that a group share, are the key factor for

Acknowledgment

The author acknowledges the help from Dr. María-del-Carmen Bravo, Área de Gobierno de Tecnologías de la Información y Apoyo Técnico al Usuario e Investigación of the Universidad Complutense, Madrid for the statistical analyses in this study. 
understanding their feelings, attitudes, values and external behaviour. In this regard, it is crucial to participate in a common narrative as the degree of consistency of a culture will depend on the internal stability of the group, the length of time it has been in existence, the intensity of learning experiences, the learning mechanisms themselves, and the clarity of the authority principles of the founders and leaders of the group (Schein, 1990, p. 111).

It seems clear from the outset that the figure of the leader is central to the creation of culture and its transmission to the rest of the team (Schein, 1988; Wilderom; Van-den-Berg; Wiersma, 2012, p. 835), especially in the case of small companies, which are born as a result of personal entrepreneurship or the decision to create startups or spin offs, though this is also true for big companies with hundreds of employees. However, there are authors who point out that a charismatic leader can sometimes be an element of resistance to change (Levay, 2010, p. 127), who can even end up blocking the progress of institutional culture. Thus, ultimately, leadership does not seem to be the central element in the construction of culture.

The study of culture in organizations has up to now been approached from the perspective of business management and organizational theory as another way of achieving efficiency in processes and ensuring greater profitability, the role of communication being given less attention (Gregory et al., 2009; Naranjo-Valencia; Jiménez-Jiménez; Sanz-Valle, 2011). However, since the beginning of the $21^{\text {st }}$ century, internal communication, its mechanisms and processes have begun to be seen as a transmission belt for an organization's basic values and assumptions (Verheyden, 2017). In the professional world it is very common to implement specific communication strategies to effectively transfer corporate identity to the people who make up the team, especially in the case of medium sized and large companies. At the same time, although many companies value their own distinct culture, there is still no clear awareness of the need to work positively on its preservation and of the possibility of intervening when improvements are necessary, or when it acts as a drag to growth.

The aim of this article is to study the organizational culture of Spanish fashion companies in order to determine whether there is a set of particular characteristics that define them, and that at the same time differentiates them from the distinct cultures of other industries. This exploratory study is particularly focused on the communication dynamics that transmit and consolidate internal culture, while aspects related to organizational theory are less relevant here given that they have been studied more frequently in the past.

\section{The fashion industry in Spain}

In Spain, the fashion industry in 2018 was made up of a total of 20,269 companies (Modaes.es, 2018), and it was the sector that registered the highest growth with respect to the previous year, with a $4 \%$ year on year rise. According to the INE [Spanish statistics office], this sector brings together three closely related industries: textiles, clothing, and leather and footwear. In December 2018 the number of employees in this industry was 141,496 people (Modaes.es, 2019).

Fashion is one of the powerhouses of Spain's economy with a GDP of 2.9 (Modaes.es, 2018) and, along with sport and tourism, it is also one of the pillars of the Spain Brand abroad. Fashion design is considered part of the creative industries (Greffe, 2006, p. 12) given that companies launch their collections on the market - between two and four times a year - in order to sell their products to consumers. Furthermore, the result of the fashion industry's activity not only fulfills a practical function in protecting us from the weather, but also satisfies other social and relational functions, all the more important in a developed society. By way of example, in autarchic societies fashion is subject to State control as a surveillance tool, while in societies with a long artistic and aesthetic tradition it is considered part of a country's cultural heritage.

Fashion, moreover, is an intangible asset insofar as it is a creative activity that must be legally protected against copying or counterfeiting. At the same time, it requires a specific type of remuneration in line with the intrinsic quality of creativity (Greffe, 2006).

There is no doubt that Spain is a world leader in terms of large-scale fashion distribution, as shown not only by Inditex (Zara, Zara Home, Pull \& Bear, Bershka, Massimo Dutti, Stradivarius, Oysho, Uterqüe), but also by other groups and companies that compete on equal terms with fashion brands from the five continents: Mango, Tendam, Desigual, Pepe Jeans, Tous, Mayoral, Sociedad Textil Lonia, Camper, Bimba y Lola, Pronovias, Liwe Española, Punt Roma, Mercal Calzados, and Adolfo Domínguez are companies with sales ranging from 25,336 (Inditex) to 113 (Bimba y Lola) million Euros annually (Modaes.es, 2018). Apart from these companies, there are thousands of small and medium enterprises that also live on creativity.

However, Spanish fashion companies face at the same time a high level of uncertainty arising from seemingly erratic change in trends and constant modifications in terms of consumer behaviour. To solve this problem, some companies use the help of trend agencies, as well as analysis and studies that attempt to predict the evolution of the market. They also seek to reduce negotiation margins with their suppliers, increase creativity, innovate in production processes, improve their distribution channels and, of course, invest in communication to build robust brands.

Furthermore, the Spanish fashion industry shrank due to the 2008 crisis, when its volume was reduced by $27.9 \%$. Spain lost 7,483 fashion companies between 2008 and 2013, and many other companies were forced to reduce their labour force in order to survive. The industrial fabric was further damaged by the liberalization of the Chinese textile industry in 
2005. In these circumstances, large numbers of young people out of jobs decided to embark on entrepreneurship in the fashion, accessories, and lifestyle sector encouraged by the ease of creating digital companies. As previously mentioned, the dependence that fashion companies have on market conditions is the reason why this industry is so sensitive to the economic and financial situation. Given that this is a sector whose final product depends on design differentiation strategies, communication and the management of intangible values play a crucial role. Social changes and trends in business management force organizations to develop these intangible aspects (corporate identity, reputation, corporate responsibility, organizational culture, and brand management) as a way to adapt to the environment. The aim of this study is to ascertain whether communication reinforces the internal culture of fashion companies in Spain, and the extent to which its role is recognized by managers and fashion experts.

\section{The competing values model}

Quinn \& Rohrbaugh (1983) proposed the competing values framework, which consists of relating the organizational culture to organizations' efficiency. This model established a double multidimensional axis with the flexibility-control variable on one side and internal-external orientation on the other. Years later, in 1991, Denison \& Spreitzer (1991, p. 5 ) revisited the competing values model and identified four types of organizational culture according to the importance given to the axes that define it, (1) group culture; (2) developmental culture; (3) rational culture; (4) hierarchical culture.

In 1999 Cameron and Quinn established a culture classification based on the concept of competing values, which gave greater importance to the environment by holding that companies do not develop in isolation but grow in a specific society and economy. The four forms of culture were (1) clan, (2) hierarchical, (3) adhocracy and (4) market (Cameron; Quinn, 2006, pp. 35-45). Gary Johns, for his part and also in 2006, insightfully determined the importance of context in organizational behaviour when he understood the relevant role played by circumstances and all those factors that surround a company when it comes to making decisions and which affect a leader's decision making, group behaviour, and its culture as a whole (Johns, 2006, pp. 386-408).

Literature based on the competing values model is still being published today (Ojeda-Hidalgo; Méndez-Valencia; Hernández-Sampieri, 2016; Hernández-Sampieri; Méndez-Valencia; Contreras-Soto, 2014; Hartnell; Yi-Ou; Kinicki, 2011) and it is safe to claim that it has been the most recurrent theoretical model over the last thirty years. However, the inclusion of professionals and experts in communication in companies' management, the sophistication of communication plans, transparency policies in companies, new digital environments, and the growth of intangibles, have led organizational culture to begin to see itself from a new perspective that incorporates communication into their success equation.

\section{Method}

As this is an initial exploratory study which does not seek to reach definitive answers but rather to approach the current situation, we decided to carry out a quantitative study in two phases; the first with experts in the fashion sector and employer branding consultancy, and a second somewhat broader one with managers and middle managers of fashion companies of different sizes. We opted for working only with professionals from the brands' central offices, with positions of responsibility and the ability to make decisions. It was further decided at this early stage not to do research on store or customer service staff in view of the scale of this area of study, the variety of professional profiles, and the geographical dispersion of points of sale.

As a starting point, in a first phase we chose to use the questionnaire on organizational culture by Denison \& Nealle (1994), which includes 60 assertions aimed at finding out the state of any given culture. Later we decided to reduce it to 40 questions (see Annex) to facilitate the obtaining of results, and then we added some specific questions to that selection, related to changes and social dynamics of our time, namely:

- Diversity in the composition of companies' governing bodies;

- Gender parity in corporate governance bodies;

- Possibility of making personal-family life compatible with a professional career at an individual level;

- Existence of specific communication mechanisms for employees;

- Possibility of making a career compatible with maternity (in the case of women);

- Use of specific communication channels addressed to employees.

Following that, we grouped the 40 questions or assertions into three broad areas: (1) corporate identity, (2) working conditions, and (3) professional career, with the aim of simplifying the identification of the major relevant culture themes in organizations. The purpose was to recognize the importance of the relationship between individuals and the corporation, and to understand the particular role of communication as an enabling factor in these dynamics.

Table 1. Thematic areas and questions (see Annex).

\begin{tabular}{|c|c|c|}
\hline Corporate identity & Working conditions & Profesional career \\
\hline $1,2,4,6,7,9,17,19,23,25,29,32,34,40$ & $5,8,13,15,18,20,26,28,30,31,36,37$ & $3,10,11,12,14,16,21,22,24,27,33,35,38,39$ \\
\hline
\end{tabular}


These three major blocks are justified in the following way:

- First, we defined the corporate identity of an organization, which includes employees' knowledge of a company's values and mission, as well as their sense of belonging. This dimension includes aspects such as the existence of specific internal communication channels for employees, cohesion between team members, the creation of a good working environment (climate) across the departments, the existence of induction programs for new employees, and the use of internal storytelling to construct a coherent story for employees through texts or images visible in work spaces. An atmosphere of motivation and enthusiasm for the common goal of the company, as well as the ethical and responsible behaviour of its leaders conclude this first block.

- Second, working conditions were defined. This refers not only to the written contract signed by each member of the organization at the beginning of their relationship with the company, but also to the psychological contract that includes other forms of remuneration, which constitute the so-called emotional salary. This dimension would include the external characteristics of offices or workplaces (workshops, factories, industrial warehouses, etc.), as well as the creative and resting areas that are so important in this type of company. It also refers to more fundamental issues such as management style, the possibility of participating in decision-making, openness to change and other job benefits such as flexibility, true gender equality, diversity in terms of age, gender and physical appearance, as well as wage proportionality according to responsibilities. The level of absenteeism as a result of a very demanding, tense or unmotivating environment or the holding of annual meetings or events are also included in this dimension.

\section{CORPORATE IDENTITY}

Degree of participation in the mission, identification with the project and sense of belonging

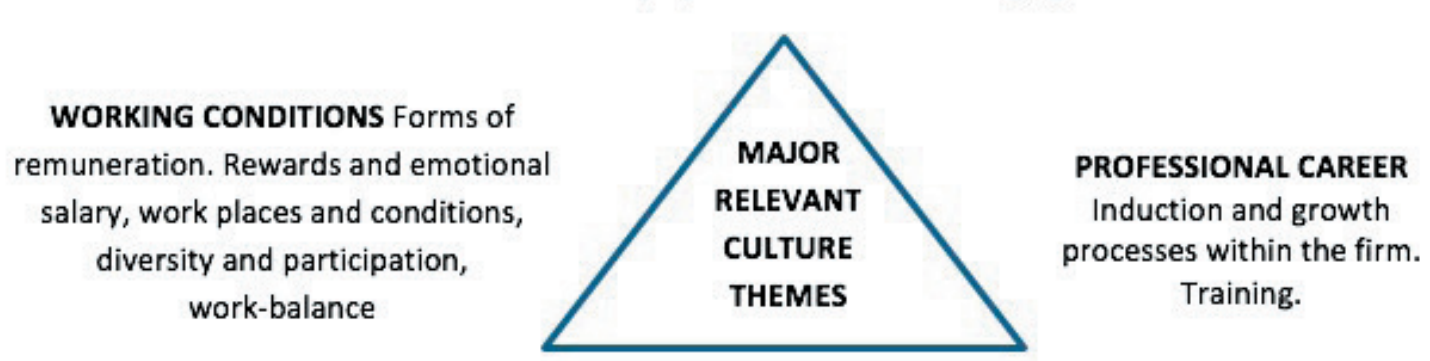

Figure 1. The three thematic blocks in which culture is manifested.

- The third thematic area covers the set of actions related to the professional career of an employee within the company. It includes the different ways of recognizing their work, the possibility of growing professionally within the company, the training offered by the organization to its employees and the emotional salary they receive as a result of their work (days/hours off for working overtime, bonuses, rewards, recognition from leaders or the team etc.), and non-economic remunerations (payments in kind, car parks, food tickets, discounts on products or services, trips etc.) Equality and diversity plans as well as team building actions would also form part of this set of values.

The possibilities to reconcile work and family life, the protection of maternity and the care of sick or dependent relatives conclude the elements that make up a person's professional career within a fashion company.

Eight experts were selected to answer the first exploratory questionnaire in January 2019, and seven of them answered it (4 men and 3 women). The selection included two top managers, an investment banking professional specializing in fashion retail, a journalist specializing in the economic dimension of the fashion industry, an expert in employer branding and cultural management of Spanish companies and SMEs and multinationals, a former manager working in academia as a fashion consultant, and a consultant specializing in retail.

Following that, in February 2019, the same questionnaire with slight adaptations was sent to 220 employees working at Spanish fashion companies. As mentioned before, all of them were top or middle managers, whose total universe in Spain is around 3,200 professionals. 40 valid responses were finally obtained. The final sample includes 20 men and 20 women working in 27 different fashion companies. Of these professionals, 17 work in large companies, 11 in medium-sized companies and 12 in small Spanish fashion companies.

Table 2. Experts surveyed in Phase 1

\begin{tabular}{|l|}
\hline E1: Investment banking \\
\hline E2: Fashion consultancy \\
\hline E3: Retail consultancy \\
\hline E4: Fashion services management \\
\hline E5: Fashion business journalist \\
\hline E6: Employer branding consultancy \\
\hline E7: Fashion business management \\
\hline
\end{tabular}


The participants worked in the following departments: purchasing, communication, management or CEO office, fashion design, ecommerce, international, marketing, operations, product, and human resources (HR).

Both samples (experts and qualified employees) answered the same questionnaire with slight style adaptations so as to enable comparison of the results of both phases. In both cases, a factor analysis was carried out using Coheris Analytics SPAD 9.1.

A principal component analysis was applied, followed by a hierarchical cluster analysis with Ward's method and Euclidean distance.

\section{Analysis of the results from the fashion sector}

An initial representation of the mean values of the experts' opinions (Figure 2) already shows that the answers tend to be grouped in the middle areas, with peaks identifying controversial aspects. This is the case of questions 15 ("In Spanish fashion companies there are resting or recreation spaces -common relax areas, gym, cafeteria, etc.- for employees") and 32 ("It is standard to share information between the departments of a Spanish fashion company"), with very low scores, but also question 6 ("In this type of companies leaders are given high authority level"), and question 7 (“Management hierarchy is clearly defined in the organization chart of Spanish fashion companies") which, on the contrary, have high scores.

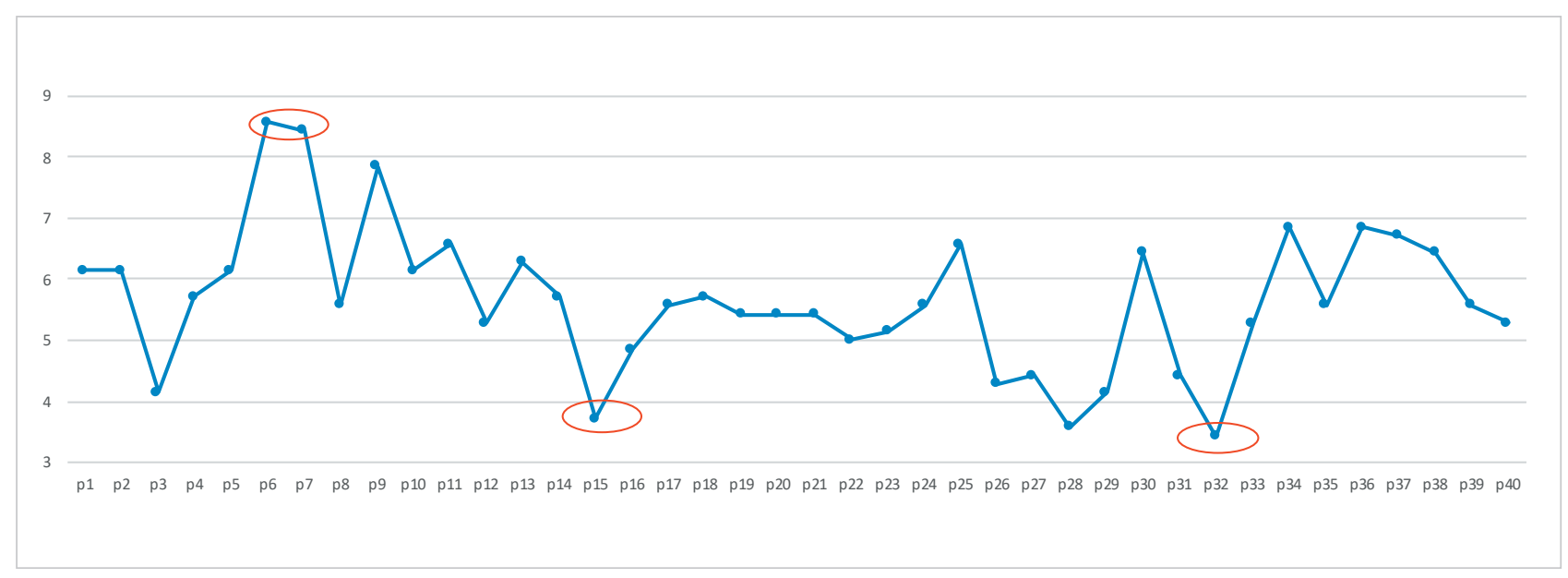

Figure 2. Distribution of expert opinions mean values

The variables that show the highest consensus are the following: "management hierarchy", "leader's authority", "personal career", "personal recognition, team trust", "leader' s ethics" and a bit behind, "creative environment". With respect to the results of the factor analysis applied to the experts' opinions (Graph 3), we decided to use an initial double axis ( 1 and 2 ) to represent the most important variables, which includes in its analysis $55.4 \%$ of the total sample. If we take the values $\geq 0.5$ located in the area to the right of Graph 3, we can distinguish the experts' profiles by selecting 17 of the 40 questions or assertions about fashion companies' culture. Of these 17 assertions, seven belong to the corporate identity dimension: 1, 2, 6, 9, 25, 34 and 40, five to the working conditions dimension: 8, 13, 28, 30 and 31 , and five to the professional career dimension: 10, 11, 24, 33 and 38.

The high weight of the first dimension (corporate identity) is notable, which may mean that as a whole, these are more informative variables in terms of the relevant values chosen by the experts, which correspond to features related to sense of belonging, leaders' authority, and team members' trust.

As previously mentioned, one of the objects of the study was to establish whether communication could play a relevant role in fashion companies' culture, to the point of providing more meaning than other aspects. Therefore, the first striking aspect is that internal storytelling shows the strongest correlation, which points to a first factor in which communication intervenes in a significant way.

In relation to the second thematic group, which refers to working conditions, we see that experts chose aspects such as team diversity, the creation of a good working environment among colleagues, providing flexible hours for employees, creating motivational environments, and promoting dynamics that allow changes in companies. Again, this aspect includes variables in which communication is a determining factor.

Third, in the group of variables related to professional career, we see that the experts believe that wages are in accordance with the responsibilities of employees, it is possible to build a professional career in fashion companies, team building actions are carried out, the active participation of employees is facilitated, and there is a strong orientation towards market results. Once again we find that many aspects include communication as a fundamental element when 
it comes to developing one's own path within Spanish fashion companies. However, Figure 3 makes more sense when it is seen in relation to Figure 4, which shows a representation of expert's opinions, and we can visually match it with the upper table in which the values are represented.

Here we observe that the retail consultant, the fashion business journalist and the academic fashion consultant are those who most agree in opinion and are thus grouped on the right side of the map. The two fashion executives, on the other hand, are the ones who distance themselves the most from the values approved by the other experts.

\section{Analysis of results of senior and middle managers of fashion firms}

The mean values for the directors and middle managers (Figure 5) reveal that the variables that stand out the most are those referring to the importance of corporate aspects (1), leaders' authority (6), trust among the people in the team (9), the possibility of growing professionally within fashion companies (11), the importance of creating a good atmosphere (13) and the possibility of taking care of family members in difficult circumstances (35). However, absenteeism due to lack of motivation (26) and resistance to change (37) also stand out for their low scores, which reflects positively on Spanish fashion companies.

A factor analysis on the views of middle managers and executives shows results that differ from those on experts. In this case, values higher than $\geq 0.6$, located in the area to the right of Figure 6, group similar opinions, which coincide in 21 of the 40 questions on fashion companies' culture. Five are found in the corporate identity dimension: 4, 23, 32, 34 and 40, seven in the working conditions dimension: 5, 13, 15, 18, 28, 30 and 31, and nine in the professional career path one: $10,11,14,16,21,22,24,33$ and 39.

When we compare both factor analyses (Figures 3 and 6), we see that there are nine coinciding aspects for experts and managers: four from the working conditions group $(13,28,30$ and 31), four from a professional background (10, 11, 24 and 33) and only one common value in the corporate identity dimension: sense of belonging (34). Although none

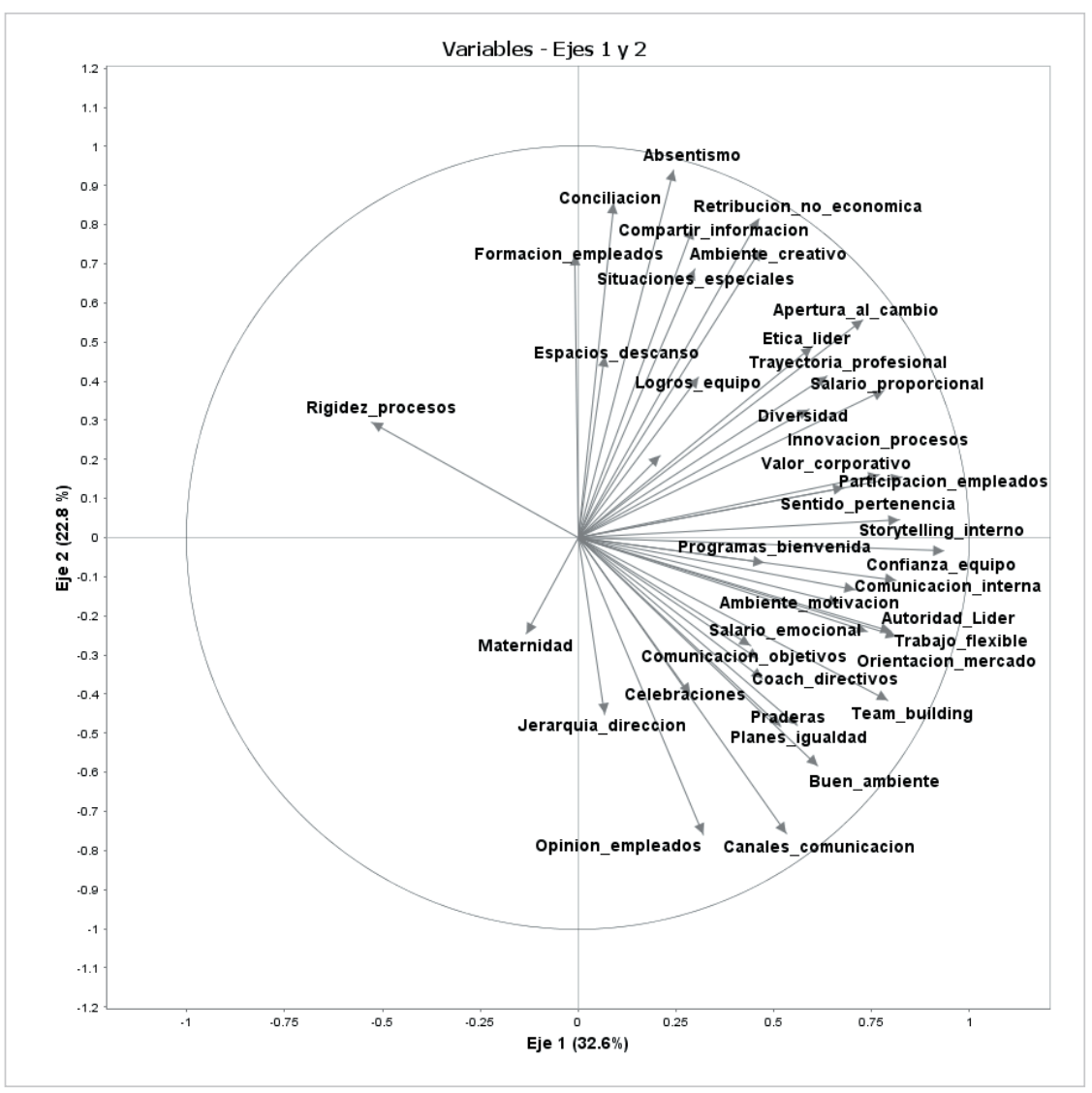

Figure 3. Factor analysis of the experts' opinions

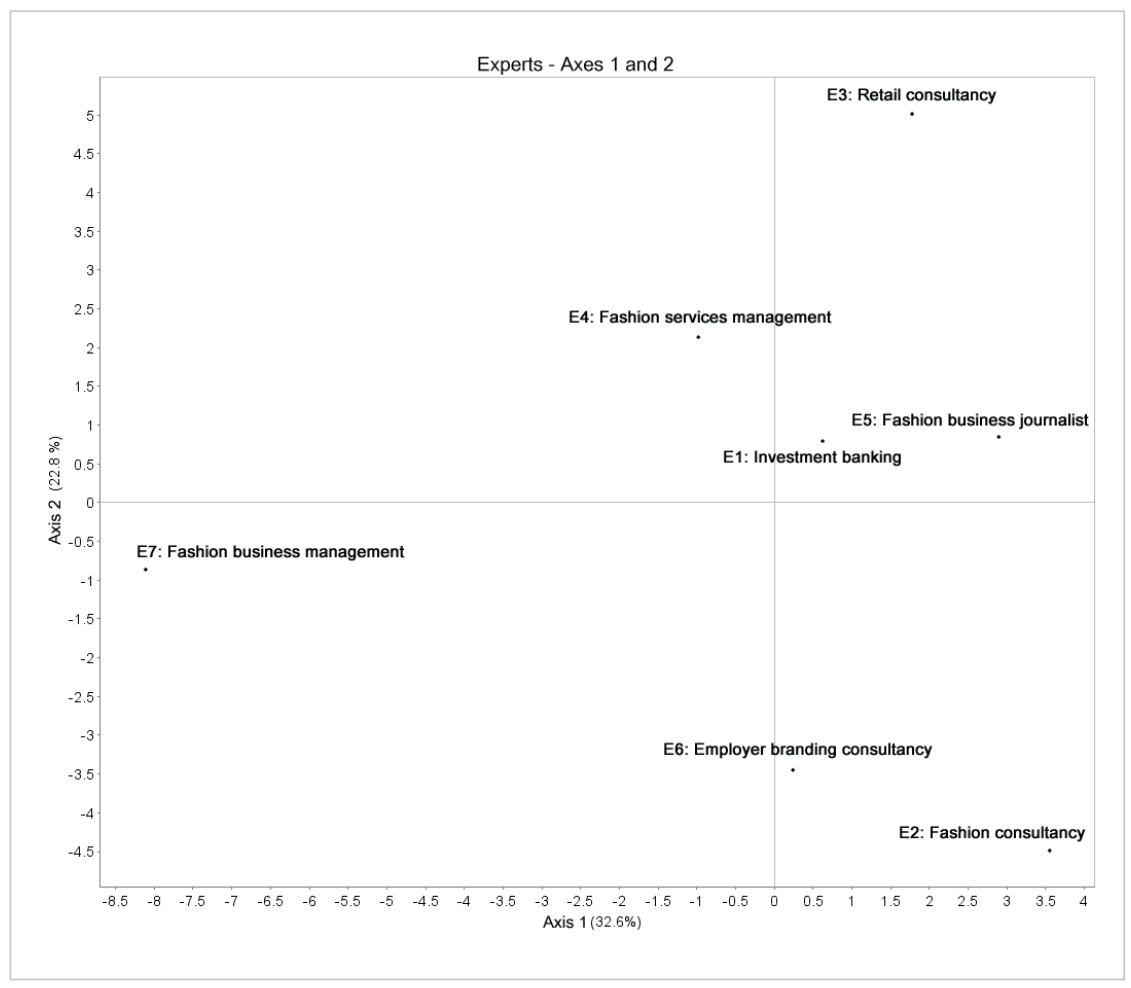

Figure 4. Distribution of expert opinions on axes 1 and 2 


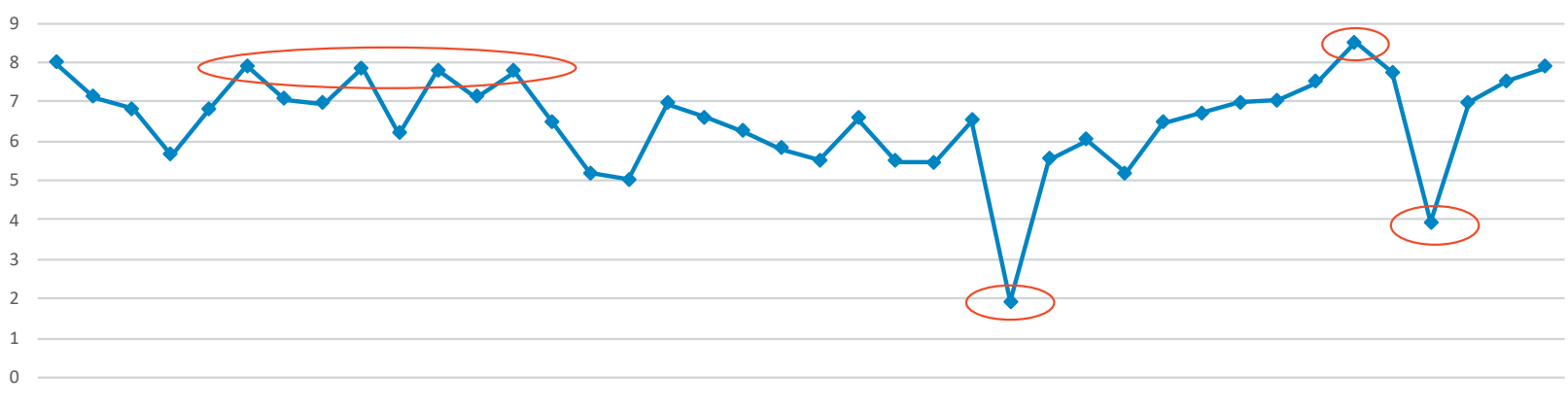

p1 p2 p3 p4 p5 p6 p7 p8 p9 p10 p11 p12 p13 p14 p15 p16 p17 p18 p19 p20 p21 p22 p23 p24 p25 p26 p27p28 p29 p30 p31 p32 p33 p34 p35 p36 p37 p38 p39 p40

Figure 5. Distribution of the mean values of directors and middle managers

of them makes specific reference to communication and its channels for reaching employees, we see that flexibility in schedules and processes, motivation and enthusiasm, the importance of having a good work environment, balance between wages and professional responsibilities, the possibility of growing professionally, the carrying out of team building actions and the active participation of employees in the development of projects clearly stand out.

In this case, access to a larger volume of data made it possible to create company clusters based on their size and turnover in order to determine whether this variable affects the conclusions. Figure 7 shows that cluster 3 , which contains a majority of small companies, is

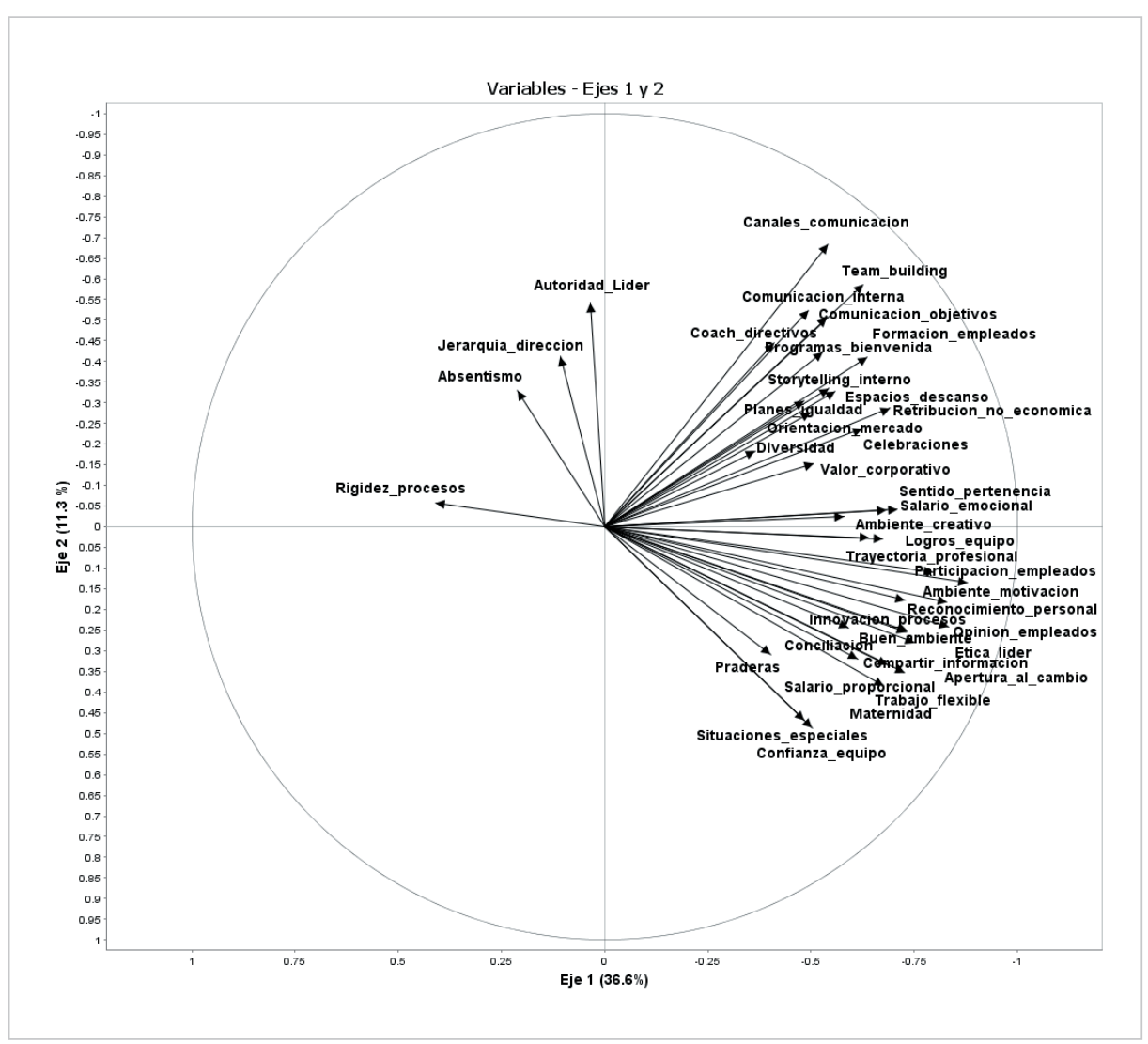

Figure 6. Factor analysis of senior and middle managers' opinions identified with aspects that have to do with trust within the team, responding to employees' special circumstances, facilitating maternity, work flexibility, proportional salaries, sharing information between departments of the same company and openness to change.

In the case of medium-sized companies, the variables most represented were the possibility of a professional career, the existence of internal communication channels and tools, the importance of a good environment, resting areas, the importance of employees' opinions, personal recognition, emotional salary, equality plans and employee training.

Finally, in the case of large companies, the aspects that in the opinion of their directors and middle managers best reflect their culture are leaders' authority, management hierarchy, innovation in processes and consideration of the special circumstances of employees.

\section{Discussion and conclusions}

The first conclusion that emerges in this preliminary study is the importance that experts and professionals in the fashion industry grant to communication as culture transmission factor. In the view of the experts, communication plays a fun- 
damental role in the consolidation of the mission and values of companies, as opposed to employees (senior and middle managers), who do not recognize this primacy. Likewise, the figure of the leader and company hierarchies, which is a relevant aspect for experts, is not that important for employees, who, however, do recognize the ethical and responsible behaviour of their managers.

This difference may respond to a series of causes. One of them is a lack of professionalism of the internal communication department in fashion companies, or the fact that a company may not have one at all. This is something that is well known by professionals in the sector, but which experts may not be aware of. After all, the day-to-day work of companies can be far removed from the somewhat more theoretical approaches of consultants and specialists.

A second conclusion is the consensus that exists in relation to the relevance of the emotional salary, flexibility in schedules and processes, and the good working atmosphere observed in Spanish fashion companies. This aspect, which is part of the so-called human resources policies, could be communicated as a differential intangible asset of fashion companies, which could provide great value if properly managed.

The third conclusion is a reflection on the working environment in Spanish fashion companies. As opposed to the image that these corporations may offer from the outside - they are companies where creativity is the core business - the executives and middle managers studied do not reflect their workplaces having creative, bohemian and inspiring spaces or that they include spaces for rest and relaxation. On the contrary, they recognize that the environment is market-oriented (sales, customers, results). Nor do they believe that there are specific communication tools for them, or that objectives are transmitted through their companies' own channels.

These results lead us to reflect on the importance of continuing to work from communication departments in the reinforcement of internal communication plans and the creation or maintenance of specific channels (newsletters, intranets, panels, social networks) for employees, so that the corporate communication channel is better maintained and can reach all levels of the organizations. At the same time, it would be advisable for fashion companies to make more use of internal storytelling to reinforce employees' sense of belonging.

\section{References}

Cameron, Kim S.; Quinn, Robert E. (2006). Diagnosing and changing organizational culture: Based on the competing values framework. San Francisco, CA: Wiley. ISBN: 9781118047057

Cújar-Vertel, Angélica-del-Carmen; Ramos-Paternina, Carlos-David; Hernández-Riaño, Helman-Enrique; López-Pereira, Jorge-Mario (2013). “Cultura organizacional: evolución en la medición”. Estudios gerenciales, v. 29, n. 126, pp. 350355.

https://dialnet.unirioja.es/servlet/articulo?codigo=5444978

Denison, Daniel R.; Neale, William (1994). Denison organizational culture survey. Ann Arbor: Aviat.

Denison, Daniel R.; Spreitzer, Gretchen M. (1991). “Organizational culture and organizational development: a competing values approach". In: Woodman, Richard W.; Pasmore, William A. (eds.). Research in organizational change and development, v. 5. pp. 1-21.

https://www.denisonconsulting.com/sites/default/files/documents/resources/denison-1991-competing-valuesapproach_0.pdf 
Garmendia, José-Antonio (2006). "El impacto de la cultura en los resultados". Revista española de investigaciones sociológicas, v. 108, n. 4, pp. 75-96.

http://www.reis.cis.es/REIS/PDF/REIS_108_051168422508981.pdf

Greffe, Xavier (2006). Managing creative enterprises. Creative industries - Booklet n. 3. WIPO.

https://www.wipo.int/edocs/pubdocs/en/copyright/938/wipo_pub_938.pdf

Gregory, Brian T.; Harris, Stanley G.; Armenakis, Achilles A.; Shook, Christopher L. (2009). "Organizational culture and effectiveness: A study of values, attitudes, and organizational outcomes". Journal of business research, v. 62, pp. 673-679. https://doi.org/10.1016/j.jbusres.2008.05.021

Hartnell, Chad A.; Yi-Ou, Amy; Kinicki, Angelo (2011). "Organizational culture and organizational effectiveness: A meta-analytic investigation of the competing values framework's. Theoretical suppositions". Journal of applied psychology, v. 96, n. 4, pp. 677-694.

https://doi.org/10.1037/a0021987

Hernández-Sampieri, Roberto; Méndez-Valencia, Sergio; Contreras-Soto, Ricardo (2014). "Construcción de un instrumento para medir el clima organizacional en función del modelo de los valores en competencia". Contaduría y administración, v. 9, pp. 229-257.

http://www.redalyc.org/articulo.oa?id=39529381010

Johns, Gary (2006). "The essential impact of context on organizational behavior". Academy of management review, $\mathrm{v}$. 31, n. 2, pp. 386-408.

https://pdfs.semanticscholar.org/8665/64951d067e9156e8410a9fcadcece4555209.pdf https://doi.org/10.5465/amr.2006.20208687

Levay, Charlotta (2010). "Charismatic leadership in resistance to change". The leadership quarterly, v. 21, pp. 127-143. https://doi.org/10.1016/j.leaqua.2009.10.010

Modaes.es (2018). "La moda consolida su peso en la economía española: defiende el 2,9\% del PIB". Modaes.es, 14 Dec. https://www.modaes.es/entorno/la-moda-consolida-su-peso-en-la-economia-espanola-defiende-el-29-del-pib.html

Modaes.es (2019). “El empleo en la moda continúa a la baja y cierra enero con una caída del 1,1\%". Modaes.es, 4 Feb. https://www.modaes.es/entorno/el-empleo-en-la-moda-continua-a-la-baja-y-cierra-enero-con-una-caida-del-11.html

Naranjo-Valencia, Julia C.; Jiménez-Jiménez, Daniel; Sanz-Valle, Raquel (2011). “Innovation or imitation? The role of organizational culture". Management decision, v. 49, n. 1, pp. 55-72.

https://doi.org/10.1108/00251741111094437

Ojeda-Hidalgo, José-Felipe; Méndez-Valencia, Sergio; Hernández-Sampieri, Roberto (2016). “El liderazgo y su relación con el Modelo de Valores en Competencia". Telos. Revista de estudios interdisciplinarios en ciencias sociales, v. 18, n. 1, pp. 17-38.

https://dialnet.unirioja.es/descarga/articulo/5655381.pdf

Quinn, Robert E.; Rohrbaugh, John (1983). “A spatial model of effectiveness criteria: Towards a competing values approach to organizational analysis". Management science, v. 29, n. 3, pp. 363-377.

https://www.jstor.org/stable/2631061

Schein, Edgar H. (1988). La cultura empresarial y el liderazgo. Una visión dinámica. Barcelona. Plaza \& Janes Editores. ISBN: 8401361079

Schein, Edgar H. (1990). “Organizational culture”. American psychologist, v. 45, n. 2, pp. 109-119. https://pdfs.semanticscholar.org/a3bf/4d014c4412f98a2b64d954e29cb9ecaa91ce.pdf

Verheyden, Mark (2017). "Social media and the promise of excellence in internal communication”. Journal of organizational ethnography, v. 6, n. 1, pp. 11-25.

https://doi.org/10.1108/JOE-09-2016-0020

Wilderom, Celeste P. M.; Van-den-Berg, Peter T.; Wiersma, Uco J. (2012). "A longitudinal study of the effects of charismatic leadership and organizational culture on objective and perceived corporate performance". The leadership quarterly, v. 23, pp. 835-848.

https://doi.org/10.1016/j.leaqua.2012.04.002 
Annex

\begin{tabular}{|c|c|c|}
\hline Corporate identity & Working conditions & Professional career \\
\hline $\begin{array}{l}\text { 1. In Spanish fashion companies, teams attach } \\
\text { great importance to corporate values. }\end{array}$ & $\begin{array}{l}\text { 5. The atmosphere in Spanish fashion compa- } \\
\text { nies is creative and bohemian (way of dres- } \\
\text { sing, flexible opening hours, office decoration } \\
\text { etc.). }\end{array}$ & $\begin{array}{l}\text { 3. The possibility of achieving a work-life ba- } \\
\text { lance characterizes Spanish fashion firms. }\end{array}$ \\
\hline $\begin{array}{l}2 \text { Fashion companies in Spain usually have spe- } \\
\text { cific internal communication channels for their } \\
\text { employees. }\end{array}$ & $\begin{array}{l}\text { 8. Team diversity (gender, age, physical con- } \\
\text { dition) is important for fashion companies in } \\
\text { Spain. }\end{array}$ & $\begin{array}{l}\text { 10. Normally, the salary in fashion companies } \\
\text { in this country is proportional to the respon- } \\
\text { sibilities that are assumed by the employee. }\end{array}$ \\
\hline $\begin{array}{l}\text { 4. There are induction programs for new em- } \\
\text { ployees in these companies. }\end{array}$ & $\begin{array}{l}\text { 13. The creation of a good atmosphere be- } \\
\text { tween colleagues is fundamental in Spanish } \\
\text { fashion companies. }\end{array}$ & $\begin{array}{l}\text { 11. Within Spanish fashion companies it is } \\
\text { common for employees to have the opportu- } \\
\text { nity to grow professionally. }\end{array}$ \\
\hline $\begin{array}{l}\text { 6. In this type of company leaders have great } \\
\text { authority. }\end{array}$ & $\begin{array}{l}\text { 15. In Spanish fashion companies there are } \\
\text { rest or leisure areas (common relaxation } \\
\text { areas, gym, cafeteria, etc.). for employees. }\end{array}$ & $\begin{array}{l}\text { 12. In Spanish fashion companies, a team's } \\
\text { achievements are more highly valued than } \\
\text { those of individuals. }\end{array}$ \\
\hline $\begin{array}{l}\text { 7. Management hierarchy is clearly defined in } \\
\text { Spanish fashion firms' organizational charts. }\end{array}$ & $\begin{array}{l}\text { 18. Spanish fashion companies usually hold } \\
\text { annual events exclusively for employees. }\end{array}$ & $\begin{array}{l}\text { 14. Recognition of employees' achievements } \\
\text { is common in companies in this sector. }\end{array}$ \\
\hline $\begin{array}{l}\text { 9. Trust between the people on the team is fun- } \\
\text { damental in Spanish fashion companies. }\end{array}$ & $\begin{array}{l}\text { 20. Open spaces where employees can work } \\
\text { together are common in the offices of Spani- } \\
\text { sh fashion companies. }\end{array}$ & $\begin{array}{l}\text { 16. It is normal for fashion companies to apply } \\
\text { forms of emotional salary to reward emplo- } \\
\text { yees (days/hours off for overtime, bonuses, } \\
\text { recognition from the leader or the team, etc.). }\end{array}$ \\
\hline $\begin{array}{l}\text { 17. Managers count on the opinion of their } \\
\text { subordinates and encourage participation in } \\
\text { Spanish fashion companies. }\end{array}$ & $\begin{array}{l}\text { 26. In Spanish fashion companies, absen- } \\
\text { teeism from work is frequent as a result of a } \\
\text { very demanding or poisoned environment, } \\
\text { poor motivation, or for other reasons. }\end{array}$ & $\begin{array}{l}\text { 21. In fashion companies in Spain there are } \\
\text { usually non-monetary forms of remuneration } \\
\text { in addition to the salary (payment in kind, } \\
\text { parking, food tickets, product discounts, trips, } \\
\text { etc.). }\end{array}$ \\
\hline $\begin{array}{l}\text { 19. In Spanish fashion companies there are } \\
\text { specific channels of communication with } \\
\text { employees (companies' own social networks, } \\
\text { newsletters, intranet, distribution lists, etc.). }\end{array}$ & $\begin{array}{l}\text { 28. It is normal for Spanish fashion compa- } \\
\text { nies to offer employees with flexible working } \\
\text { hours. }\end{array}$ & $\begin{array}{l}\text { 22. Training courses for employees are offe- } \\
\text { red/taught in Spanish fashion companies. }\end{array}$ \\
\hline $\begin{array}{l}\text { 23. Spanish fashion companies communicate } \\
\text { objectives and behaviour patterns expected } \\
\text { from employees through internal notes, me- } \\
\text { mos, etc. }\end{array}$ & $\begin{array}{l}\text { 30. The atmosphere in Spanish fashion com- } \\
\text { panies is usually one of motivation and en- } \\
\text { thusiasm. }\end{array}$ & $\begin{array}{l}\text { 24. Spanish fashion companies carry out team } \\
\text { building actions to improve the sense of be- } \\
\text { longing and of the team among their emplo- } \\
\text { yees. }\end{array}$ \\
\hline $\begin{array}{l}\text { 25. In Spanish fashion companies, the origins } \\
\text { of a firm (narration of the founder's history, of } \\
\text { the initial moments or the historical evolution } \\
\text { of the company) are often used to provide con- } \\
\text { sistency to the team. }\end{array}$ & $\begin{array}{l}\text { 31. Fashion companies in Spain tend to have } \\
\text { flexible processes in which it is possible to in- } \\
\text { troduce changes. }\end{array}$ & $\begin{array}{l}\text { 27. In companies in the fashion sector, speci- } \\
\text { fic action plans are carried out to achieve full } \\
\text { gender equality (participation on boards of } \\
\text { directors, equal working conditions and sala- } \\
\text { ries, professional promotion, etc.). }\end{array}$ \\
\hline $\begin{array}{l}\text { 29. In companies in the fashion sector in Spain, } \\
\text { coaching is commonly used for executives. }\end{array}$ & $\begin{array}{l}\text { 36. Fashion sector firms incorporate impro- } \\
\text { vements in processes (product, operations, } \\
\text { quality, supply, purchases) over time. }\end{array}$ & $\begin{array}{l}\text { 33. Spanish fashion companies facilitate the } \\
\text { active participation of employees in the deve- } \\
\text { lopment of projects. }\end{array}$ \\
\hline $\begin{array}{l}\text { 32. It is standard to share information between } \\
\text { departments of a Spanish fashion company. }\end{array}$ & $\begin{array}{l}\text { 37. In Spanish fashion companies it is very di- } \\
\text { fficult to break the inertia and there is great } \\
\text { resistance to change. }\end{array}$ & $\begin{array}{l}\text { 35. Spanish fashion companies make it easier } \\
\text { for employees to deal with special personal } \\
\text { circumstances (illness of spouses, children or } \\
\text { close relatives, sick leave, etc.) when the case } \\
\text { arises. }\end{array}$ \\
\hline $\begin{array}{l}\text { 34. Employees in Spanish fashion companies } \\
\text { have a sense of belonging and are proud to be } \\
\text { part of them. }\end{array}$ & & $\begin{array}{l}\text { 38. It is common for the office team of a Spa- } \\
\text { nish fashion company to be market and cus- } \\
\text { tomer-oriented (sales, customer service, CRM, } \\
\text { purchase data analysis etc). }\end{array}$ \\
\hline $\begin{array}{l}\text { 40. Ethics and responsible behaviour guide } \\
\text { Spanish fashion companies managers'. }\end{array}$ & & $\begin{array}{l}\text { 39. A young woman can pursue a career in a } \\
\text { Spanish fashion company while having seve- } \\
\text { ral children throughout her time in the com- } \\
\text { pany. }\end{array}$ \\
\hline
\end{tabular}

